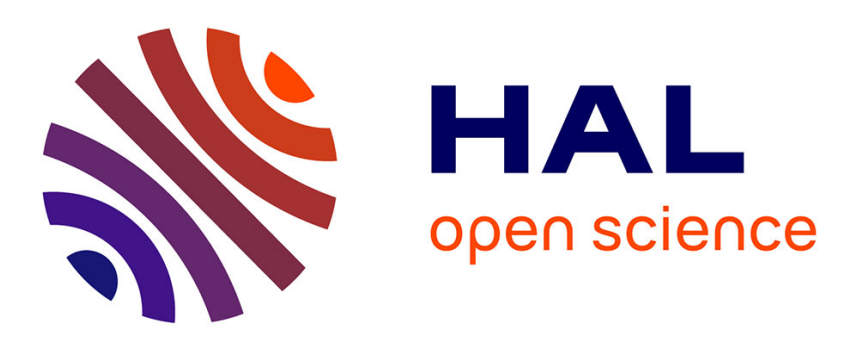

\title{
Influence of bromide and iodide on the formation of disinfection by-products in drinking water treatment
}

Justine Criquet, Sébastien Allard

\section{To cite this version:}

Justine Criquet, Sébastien Allard. Influence of bromide and iodide on the formation of disinfection by-products in drinking water treatment. Analysis and Formation of Disinfection Byproducts in Drinking Water, 92, Elsevier, pp.117-138, 2021, Comprehensive Analytical Chemistry, 10.1016/bs.coac.2021.01.004 . hal-03405637

\section{HAL Id: hal-03405637 \\ https://hal.science/hal-03405637}

Submitted on 27 Oct 2021

HAL is a multi-disciplinary open access archive for the deposit and dissemination of scientific research documents, whether they are published or not. The documents may come from teaching and research institutions in France or abroad, or from public or private research centers.
L'archive ouverte pluridisciplinaire HAL, est destinée au dépôt et à la diffusion de documents scientifiques de niveau recherche, publiés ou non, émanant des établissements d'enseignement et de recherche français ou étrangers, des laboratoires publics ou privés. 


\title{
Influence of bromide and iodide on the formation of disinfection by-products in drinking water treatment
}

\author{
Justine Criquet $^{1}$ and Sébastien Allard ${ }^{2}$
}

1. Univ. Lille, CNRS, UMR 8516 - LASIRE, Laboratory of Advanced Spectroscopy for the Interactions, Reactivity and Environment, F-59000 Lille, France

2. Curtin Water Quality Research Centre, School of Molecular and Life Sciences, Curtin University, Perth, WA, Australia

\begin{abstract}
The speciation of disinfection by-products (DBPs) formed during oxidative processes strongly depends on the presence of bromide and iodide. These ubiquitous elements can be found in water at various concentrations, $\mathrm{Br}^{-}$from a few $\mu \mathrm{g} \mathrm{L}^{-1}$ to a few $\mathrm{mg} \mathrm{L}^{-1}$ and $\mathrm{I}^{-}$typically from 0.5 to $100 \mu \mathrm{g} \mathrm{L}^{-1}$. The hypohalous acid (HOX) formed during oxidative treatment is the key intermediate. The formation of DBPs will depend on the ability of the oxidant to form HOX from the oxidation of halides and its further stability in the treated water. The reactivity of $\mathrm{Br}^{-}, \mathrm{I}^{-}, \mathrm{HOBr}, \mathrm{BrO}^{-}, \mathrm{HOI}$ and $\mathrm{IO}^{-}$with various oxidants (chlorine, bromine, ozone, chloramines and chlorine dioxide) and corresponding rate constants are compiled and compared in this paper to explain the propensity of various disinfection processes to form halogenated DBPs. The detrimental effects (i.e. enhanced toxicity of the treated waters due to the higher toxicity of I-DBPs and Br-DBPs compared to their chlorinated analogues, and enhanced NDMA formation in presence of bromide) and the beneficial effects of the presence of halides (bromide catalysis of iodate formation, enhanced micropollutant removal in presence of bromide) are presented and discussed. Finally, strategies to avoid/mitigate the formation of DBPs or to remove DBPs are presented.
\end{abstract}

Keywords: halides, halogenated disinfection by-products, chlorination, chloramination, bromate 


\section{Introduction}

Climate change, expanding populations and drought have resulted in water scarcity in many urban and regional centres and effective water resources management during periods of drying climate is of crucial importance. Scarcity of water has led to an increasing need for water utilities to rely on lower quality source waters, which often contain elevated concentrations of bromide/iodide and DOM. Increasingly stringent guidelines for maximum DBP concentrations place additional pressure on water utilities to access good quality source water or, in its absence, to identify better methods to treat and manage poorer quality sources. The formation of iodinated and brominated disinfection by-products (Br-DBPs) is of concern, since these compounds have been shown to be more toxic than their chlorinated analogues and generally an increased toxicity has been observed in chlorinated waters containing bromide or iodide[15] (Figure 1). Iodoacetic acid is the most genotoxic compound identified to-date[4]. In addition, I-DBPs are associated with a medicinal taste and odor in distributed waters. I-THMs have a low odor threshold ranging from 0.03 to $8.9 \mu \mathrm{g} \mathrm{L}^{-1}$, iodoform being the most problematic compound[6,7]. Hence, in the last decade, the behaviour of bromide/iodide along the treatment train and distribution system has been extensively studied. The knowledge gained from these studies allowed to develop new treatment strategies to mitigate the impact of bromide/iodide on the formation and toxicity of DBPs.

Bromide and iodide are naturally occurring at various concentrations worldwide. In fresh waters, bromide concentrations are in the range of a few $\mu \mathrm{g} \mathrm{L}^{-1}$ to a few $\mathrm{mg} \mathrm{L}^{-1}[8,9]$, while iodide concentrations are much lower, usually in the range 0.5 to $100 \mu \mathrm{g} \mathrm{L}^{-1}$ and often below $20 \mu \mathrm{g} \mathrm{L}-1[10,11]$. The highest concentrations encountered are usually due to the impacts of seawater through direct salt-water intrusion or bedrocks formed from marine sediments. The concentrations of bromide and iodide in seawater are relatively constant, with a $\mathrm{Br} / \mathrm{I}^{-}$ratio slightly higher than 1000 . The concentration of bromide is around $67 \mathrm{mg} \mathrm{L}^{1}$ and iodine (mostly in the form of iodate in seawater) is between 45 and $60 \mu \mathrm{g} \mathrm{L} \mathrm{L}^{-1}[12,13]$. However, in fresh water, no particular trend can be observed[9]. In most cases iodide is not detected while in some regions, a large proportion of water samples contained high concentration of iodide $>150 \mu \mathrm{g} \mathrm{L}^{-1}(72 \%$ of 950 samples in [14]). 
Anthropogenic activities have also been found to increase the concentrations of bromide[15] and iodide in fresh waters[16]. Especially, environmental impact studies on hydraulic fracturing have shown high halide concentration in their effluent ( $\mathrm{I}^{-}$up to $54 \mathrm{mg} \mathrm{L}^{-1}$ and $\mathrm{Br}^{-}$up to $1.9 \mathrm{~g} \mathrm{~L}^{-1}$ )[17]. Overall, increasing halide concentrations due to climate change and increasing pressure on water resources are expected (sea water intrusion in coastal aquifers and lower dilution rates due to water scarcity) and may affect the type and concentrations of DBPs formed and their associated toxicity.

\section{Hypohalous acid: a key intermediate in the formation of}

\section{DBPs}

In this chapter, chlorine, bromine or iodine will be used to refer to both corresponding hypohalous acid (HOX) and/or hypohalite $\left(\mathrm{XO}^{-}\right)$species.

Chlorine is the most commonly used drinking water disinfectant worldwide. Therefore, understanding the chemistry of $\mathrm{HOCl}$ is crucial in water treatment processes. Chlorine participates in numerous reactions during drinking water treatment, including oxidation/disinfection and halogenation of dissolved organic matter (DOM), to form chlorinated organic disinfection by-products (DBPs) (Figure 1). In the presence of bromide and iodide, $\mathrm{HOBr}$ and $\mathrm{HOI}$ may be formed by various oxidants and react, similar to chlorine, with DOM to form Br-DBPs and I-DBPs (Figure 1). Therefore, it is important to understand and control the formation and reactivity of HOX since it is a key intermediate in the formation of DBPs. In fact, the formation of $\mathrm{HOBr}$ and $\mathrm{HOI}$ strongly depends on the type of oxidant used for disinfection.

\section{Figure 1}

Bromide is rapidly oxidized by $\mathrm{HOCl}$ with a second order rate constant (k) of $1550 \mathrm{M}^{-1} \mathrm{~s}^{-1}$ while $\mathrm{ClO}^{-}$is not reactive with bromide (Table 1)[18]. Ozone reacts slowly with bromide to form $\mathrm{HOBr}$ with $\mathrm{k}$ of 160 $\mathrm{M}^{-1} \mathrm{~s}^{-1} \cdot \mathrm{ClO}_{2}$ is unreactive with bromide and therefore does not form $\mathrm{HOBr}$. In the case of chloramination, bromide reacts slowly with $\mathrm{NH}_{2} \mathrm{Cl}$ to form brominated amines and not $\mathrm{HOBr}$ (a discussion is provided in the following section). 
The reactivity of the different oxidants with iodide is different from bromide. Iodide is quickly oxidised by $\mathrm{HOCl}\left(\mathrm{k}=4.3 \times 10^{8} \mathrm{M}^{-1} \mathrm{~s}^{-1}\right)$ but much more slowly by $\mathrm{ClO}^{-}\left(\mathrm{k}<30 \mathrm{M}^{-1} \mathrm{~s}^{-1}\right)$. Ozone oxidises iodide quickly with $\mathrm{k}=2 \times 10^{9} \mathrm{M}^{-1} \mathrm{~s}^{-1}$. Both processes lead to the formation of HOI. In contrast, the oxidation of iodide by $\mathrm{ClO}_{2}$ is possible under typical drinking water treatment conditions $\left(\mathrm{k}=1870 \mathrm{M}^{-1} \mathrm{~s}^{-1}\right)$. However, it does not form HOI but the iodine radical $\mathrm{I}^{\bullet}[19]$. Compared to bromide, iodide is oxidised by monochloramine to $\mathrm{HOI}\left(\mathrm{k}=2.4 \times 10^{3} \mathrm{M}^{-1} \mathrm{~s}^{-1}\right.$ at $\mathrm{pH}$ 7) (Table 1). If $\mathrm{HOBr} / \mathrm{BrO}^{-}$are present in solution, these species are also able to oxidise iodide to HOI at a high rate with $\mathrm{k}$ of $5 \times 10^{9} \mathrm{M}^{-1} \mathrm{~s}^{-1}$ and $6.8 \times 10^{5} \mathrm{M}^{-}$ ${ }^{1} \mathrm{~S}^{-1}$ respectively (Table 2).

The formation and speciation of DBPs will depend on the competition between the different oxidants and the DOM reactive sites for reaction with $\mathrm{HOBr}$ and $\mathrm{HOI}$. If the hypohalous acids are stable in solution, they will have sufficient time to react with DOM and form organic DBPs. If the hypohalous acid are reacting quickly with the oxidant, inorganic DBPs such as bromate $\left(\mathrm{BrO}_{3}^{-}\right)$or iodate $\left(\mathrm{IO}_{3}^{-}\right)$will be formed.

\section{Table 1}

\subsection{Inorganic disinfection by-product formation}

As mentioned previously, once HOX is formed, one option is that it is further oxidised by the oxidants present in solution (Figure 1). As shown in Table 2, only ozone is able to further oxidize reactive bromine and more precisely $\mathrm{BrO}^{-}$with a $\mathrm{k}$ of $110 \mathrm{M}^{-1} \mathrm{~s}^{-1}$. The reactivity of other oxidants as well as the disproportionation of $\mathrm{HOBr}$ are negligible under typical drinking water treatment conditions[26]. The oxidation of $\mathrm{BrO}^{-}$by ozone leads to the formation of bromate[28], which is a potential human carcinogen and is regulated in most of countries with a drinking water guideline of $10 \mu \mathrm{gL}^{-1}$.

In comparison to $\mathrm{HOBr}$, $\mathrm{HOI}$ may be oxidised by a wide range of oxidants and leads to the formation of iodate $\left(\mathrm{IO}_{3}^{-}\right)$, which in contrast to bromate is a non-toxic and a stable form of iodine in drinking water[29]. $\mathrm{HOCl} / \mathrm{ClO}^{-}$are able to oxidize $\mathrm{HOI}$ (but not $\mathrm{OI}^{-}$) to $\mathrm{IO}_{3}{ }^{-}$at a low rate with $\mathrm{k}$ of $8.2 \mathrm{M}^{-1} \mathrm{~s}^{-1}$ and $52 \mathrm{M}^{-1} \mathrm{~s}^{-1}$, respectively. The half-life of $\mathrm{HOI}$ in presence of chlorine at $\mathrm{pH} 7$ is $\sim 40 \mathrm{~min}$, which means that $\mathrm{HOI}$ is quite stable in solution (Table 2). However, in presence of $\mathrm{HOBr} / \mathrm{BrO}^{-}$the half-life of $\mathrm{HOI}$ is drastically reduced to $\sim 2$ min with $\mathrm{k}$ of $1.9 \times 10^{6} \mathrm{M}^{-1} \mathrm{~s}^{-1}$ and $1.810^{3} \mathrm{M}^{-1} \mathrm{~s}^{-1}$, for the reaction of $\mathrm{OI}^{-}$ 
with $\mathrm{HOBr} / \mathrm{BrO}^{-}$, respectively[30]. The oxidation of $\mathrm{HOBr} / \mathrm{BrO}^{-}$by $\mathrm{HOI}$ is not significant. Ozone reacts quickly with HOI/OI- with $\mathrm{k}$ of $3.6 \times 10^{4} \mathrm{M}^{-1} \mathrm{~s}^{-1}$ and $1.6 \times 10^{6} \mathrm{M}^{-1} \mathrm{~s}^{-1}$, respectively. Finally, chloramine is not able to oxidize reactive iodine to iodate. Therefore, $\mathrm{HOI} / \mathrm{OI}^{-}$will be stable in solution during chloramination and be able to react with any DOM present.

\section{Table 2}

\subsection{Organic disinfection by-product formation}

If HOX is not oxidised to oxyhalides, then it reacts with DOM, to form organic halogenated DBPs. As shown in Table 2, only ozone is able to oxidise $\mathrm{BrO}^{-}$to bromate and at a slow rate. Therefore, when bromine reactive species are present in solution, they will be stable and a high formation of organic $\mathrm{Br}$ DBPs is expected[26,33]. Similarly, chlorine will oxidise iodine at a slow rate and therefore high concentration of I-DBPs are expected[34]. During ozonation, iodine will be quickly oxidised to iodate, and low formation of I-DBPs is expected. However, during chloramination, $\mathrm{NH}_{2} \mathrm{Cl}$ is not able to oxidise iodine and high formation of I-DBPs is expected.

Bromide is ubiquitous in natural waters, and depending on its concentrations, the contact time and the physico-chemical characteristics of the water, $\mathrm{HOBr}$ rather than $\mathrm{HOCl}$ may become the dominant oxidant/disinfectant and halogenating agent during chlorination. In many cases, the reactivity of $\mathrm{HOBr}$ in oxidation and halogenation reactions far outweighs the reactivity of $\mathrm{HOCl}[35-39]$. It has been shown that second order rate constants for reactions with phenolic compounds are on average 3000 times higher for $\mathrm{HOBr}$ compared to $\mathrm{HOCl}[26]$. Hence, the formation of Br-DBPs is kinetically favoured compared to the formation of Cl-DBPs.

$\mathrm{HOBr}$ reacts through two different pathways, electrophilic substitution and addition reactions which leads to the formation of Br-DBPs or electron transfer which leads to the oxidation of the DOM components and the release of bromide. It was shown using DOM extracts that around $20 \%$ of the reaction leads to halogenation and the major part of the oxidants reacts with DOM through electron transfer and leads to the release of bromide in solution[35]. The partition between halogenation and 
electron transfer reaction strongly depends on the nature of the organics, for example the relative position of hydroxyl moieties on the benzene ring. The ortho and para position of the dihydroxybenzenes (e.g. catechol and hydroquinone) lead to the quantitative formation of quinones and do not exhibit substantial halogenation; in contrast to the meta position which undergoes full halogenation[35] (e.g. resorcinol, which is known to have a high yield of THM formation[40]). In real systems, chlorine is always in excess to provide a disinfectant residual. Even though, $80 \%$ of the bromide is released in the water after electron transfer reaction it can then be re-oxidized by $\mathrm{HOCl}$, resulting in a bromide-catalysis and additional formation of Br-DBPs. As long as there is a disinfectant residual as well as organic precursors, such as DOM present, bromide will enhance the disinfectant demand and eventually $100 \%$ of the initial bromide will be transferred to Br-DBPs[33].

Iodine is also generally more reactive towards organic compounds than reactive chlorine. HOI generally exhibits an intermediate reactivity between $\mathrm{HOBr}$ and $\mathrm{HOCl}[41]$. There is no comprehensive study to date on the mechanism of iodine reaction with DOM. A similar behaviour as chlorine and bromine is expected, i.e. electrophilic substitution/addition reactions and electron transfer reactions. However, in presence of excess chlorine, while iodide will be recycled, both I-DBPs and iodate will be formed. If chloramination is used for disinfection, as $\mathrm{NH}_{2} \mathrm{Cl}$ is not able to oxidise $\mathrm{HOI}$ to iodate, $100 \%$ of the initial iodide is expected to be transferred to I-DBPs as iodide will be recycled and re-oxidised to HOI by $\mathrm{NH}_{2} \mathrm{Cl}$.

Figure 2

\section{Role of bromide during monochloramination}

Monochloramine $\left(\mathrm{NH}_{2} \mathrm{Cl}\right)$ has increasingly been used over the last decade as an alternative disinfectant to chlorine for drinking water distribution systems due to its greater stability and lower potential to form regulated DBPs [42-44]. However, although $\mathrm{NH}_{2} \mathrm{Cl}$ is more stable than $\mathrm{HOCl}$, it can still decompose or react with the water matrix to form other haloamines, which may be more reactive than $\mathrm{NH}_{2} \mathrm{Cl}$ and form more potent DBPs. Therefore, not only the concentration, but also the speciation, is an important 
parameter, which needs to be considered. $\mathrm{NH}_{2} \mathrm{Cl}$ can react with bromide, albeit slowly, and therefore the chemistry of the system becomes even more complex.

Various haloamines may form from reactions between chlorine, bromide and ammonia (e.g. chloramines, bromamines and bromochloramines) (Figure 2). Monobromamine $\left(\mathrm{NH}_{2} \mathrm{Br}\right)$ can be formed from the reaction of $\mathrm{HOBr}$ and $\mathrm{NH}_{3}$ or $\mathrm{NH}_{3} \mathrm{Cl}^{+}$and $\mathrm{Br}$; bromochloramine $(\mathrm{NHBrCl})$ may be formed from the reaction of $\mathrm{HOBr}$ with $\mathrm{NH}_{2} \mathrm{Cl}[45-47]$. A major concern related to the formation of bromamines is that they can accelerate the decay of $\mathrm{NH}_{2} \mathrm{Cl}[48]$ and react with DOM. There is a paucity of reported information on the reactivity of bromamines, but as for $\mathrm{HOBr}$, it has been shown that the reactivity of bromamines was higher than that of its chlorine analogues for the reaction with acetic acid[49], which confirms earlier studies showing that $\mathrm{NHBrCl}$ was more reactive than $\mathrm{NH}_{2} \mathrm{Cl}[50]$. It has been shown that brominated amines form halogenated phenols via electrophilic aromatic substitution[43]. The presence of bromide in a chloraminated system was also found to catalyze DOM oxidation[48]. It is thus hypothesized that the reaction of bromamines with DOM in raw and treated waters may enhance the formation of undesired Br-DBPs, as well as accelerate the decay of chloramine[51]. In addition to inorganic halamines, organic halamines may form from the reaction of inorganic halamines or chlorine/bromine with dissolved organic nitrogen (i.e., DON, nitrogenous moieties in DOM) and participate to the formation of $\mathrm{Br}-\mathrm{DBPs}[26,52]$. Therefore, not only is the concentration of the primary oxidant important, but secondary oxidants which are formed from reaction with bromide may also be important during chloramination.

\section{The detrimental effects of halide}

\subsection{Br-DBPs and/or I-DBPs induce a highest toxicity}

Br-DBPs and I-DBPs are of particular concern since they have been reported to be more cytotoxic and genotoxic than their chlorinated and brominated analogues[4,53,54]. Within a class of DBPs, the toxicity increases in the order $\mathrm{Cl}<\mathrm{Br}<\mathrm{I}-\mathrm{DBPs}[4]$. Yang et al.[5] demonstrated that the cytotoxicity and genotoxicity of waters treated by chlorine or chloramines was correlated to the total formation of 
iodinated and brominated organic compounds named $\mathrm{TOI}$ and $\mathrm{TOBr}$ (total organic halides). As expected, the toxicity increased with increasing concentration of bromide and iodide. It is interesting to note that the toxicity was inversely correlated to the formation of chlorinated organic compounds (TOCl), since the formation of Cl-DBPs decreased with increasing concentration of bromide and iodide. This is due to the competition between $\mathrm{HOCl}, \mathrm{HOBr}$ and $\mathrm{HOI}$ for DOM reactive sites. $\mathrm{As} \mathrm{HOBr}$ and HOI react faster with DOM, this induced a shift from Cl-DBPs to Br- and I-DBPs formation.

Another approach to estimate the DBP-mediated toxicity is to use the sum of the measured concentrations of individual disinfection by-products (DBPs) divided by their respective Chinese hamster ovary $(\mathrm{CHO})$ cell cytotoxicity $\mathrm{LC}_{50}$ (lethal concentration for $50 \%$ of a population) values to estimate the DBP associated cytotoxicity of disinfected waters. This gives the contribution of each DBP to the overall calculated toxicity and allows the prioritization of DBPs not only based on their concentrations but also their toxicity. It has recently been showed that the additivity of individual toxicities was representative of the $\mathrm{CHO}$ cell cytotoxicity associated with known DBPs in real disinfected waters[55]. Several studies reported the importance of Br-and/or I- DBPs over Cl-DBPs using this approach[55-60]. I-DBPs exhibiting particularly high toxicity, despite their usually much lower concentration in treated waters may be important toxicity drivers. I-THMs using this approach showed a similar or up to 2.1 fold higher toxicity than regulated THMs[2,61]. Bromoacetic acid, despite its relatively low concentration, was responsible for more than $60 \%$ of the relative toxicity related to the formation of 17 different HAAs and THMs[59]. In addition to toxicity, brominated by-products from different antibiotics have been shown to accumulate in aquatic organism more easily than their chlorinated analogues[62].

\subsection{Bromide enhanced NDMA formation}

$\mathrm{N}-\mathrm{Nitrosamines} \mathrm{have} \mathrm{long} \mathrm{been} \mathrm{recognised} \mathrm{as} \mathrm{extremely} \mathrm{potent} \mathrm{carcinogens,} \mathrm{and} \mathrm{their} \mathrm{significance} \mathrm{in}$ drinking water and wastewaters has been recognised in numerous studies[63-65]. The most common and most extensively studied N-Nitrosamines being N-nitrosodimethylamine (NDMA). Even though NDMA does not contain any halogen, its formation may be influenced by the presence of bromide. It 
has been found that not only chloramines but also $\mathrm{NH}_{2} \mathrm{Br}$ and $\mathrm{NHBrCl}$ were precursors in the formation of the NDMA during chloramination[43,66-69]. Another study reported that the formation of NDMA was catalysed by bromide during ozonation[70]. These studies highlight the fact that the presence of halogens may affect the formation of toxic DBPs which are not necessarily halogenated DBPs.

\section{The beneficial effects of halide on DBP formation}

\subsection{Bromide-catalysed iodate formation and mitigation of I-DBPs}

As shown in Table 2, $\mathrm{HOBr} \mathrm{BrO}^{-}$oxidises iodine at a much higher rate than chlorine. In natural waters, high concentrations of iodide are usually accompanied by the presence of a substantial amount of bromide. During chlorination, chlorine is always in large excess compared to bromide and iodide. As discussed previously, the rate of iodate formation is relatively low during chlorination. Therefore, iodine is stable in solution and may react with DOM to form I-DBPs. In presence of bromide the formation of non-toxic iodate increases and the formation of I-DBPs decreases. During this process, bromide is released in solution and can react with chlorine to re-form bromine. Therefore, small quantities of bromide are able to greatly enhance the formation of iodate. It has been shown that increasing the bromide concentration from 40 to $200 \mu \mathrm{g} / \mathrm{l}$ increased the conversion of iodide to iodate from 45 to $90 \%$ while the I-incorporation into I-THMs decreased from 10 to $2 \%[30]$.

\subsection{Enhanced micropollutant degradation in presence of $\mathrm{Br}^{-}$}

One consequence of the generally higher reactivity of $\mathrm{HOBr}$ compared to $\mathrm{HOCl}$ is the enhanced micropollutant degradation in presence of bromide during chlorination. As stated earlier, $\mathrm{HOBr}$ reacts in average 3000 times faster with aromatic compounds than $\mathrm{HOCl}$. A large number of micropollutants contain phenolic groups in their structure. This phenomenon has been demonstrated for $17 \alpha$ ethinylestradiol[39], in addition to the faster degradation, the bromination process is also able to destroy the estrogenic properties of this compound[71]. Examples with different reactive moieties are discussed in details in Heeb et al.[26]. Lately, numerous studies confirmed the increased degradation of 
micropollutants in presence of bromide such as benzophenone[72], bromacil[73] ephedrine[74], ciprofloxacin and lomefloxacin[62], methylparaben and halogenated by-products[75] and polycyclic aromatic hydrocarbons[76].

The enhanced degradation of micropollutants is not clear during advanced oxidation processes (AOPs). The presence of bromide results in both an increased rate of micropollutant degradation[78,79] and no or detrimental effects depending on the micropollutant and the experimental conditions[80]. However, Hua et al. [81] showed that the presence of bromide during UV/chlorination of wastewater effluents induced a decrease of the acute toxicity and genotoxicity of the treated effluents despite the increase of toxic brominated DBPs.

\section{Mitigation of brominated and iodinated DBPs}

Different mitigation strategies have been proposed in recent years to mitigate the formation of DBPs. There are different options for removing the precursors, i.e. halogens and/or DOM or removing the DBPs once formed. These processes based either on specific halide removal, combination of oxidants, and physical removal such as adsorption or stripping are at different stages between development and application. Common water treatments trains (e.g. coagulation, activated carbon adsorption, membrane filtration and ion exchange) are designed to remove DOM and could be efficient to meet the DOC quality standards where they exist. However, these concentrations (e.g. recommendation of $2 \mathrm{mgC} / \mathrm{L}$ in France) could be sufficient to induce the formation of toxic and/or odorous DBPs especially in presence of bromide and iodide. In addition, the removal of DOM generally promotes the formation of brominated compounds favouring the reaction of chlorine with $\mathrm{Br}^{-}$instead of DOM. This could induce a greater toxicity, despite an overall decrease of DBP concentrations[82-86]. There is currently no economically feasible method to remove the halogens precursors of DBP, bromide and iodide. 


\subsection{Removal of halides}

Some research has concentrated on the selective adsorption of bromide and iodide on synthetic silverdoped materials[87-89]. This process is based on the high affinity of halide ions towards silver ions. The solubility product for $\mathrm{AgX}$ (for $\mathrm{X}=\mathrm{Cl}^{-}, \mathrm{Br}^{-}, \mathrm{I}^{-}$) decreases in the order $\mathrm{Cl}^{-}\left(\mathrm{K}_{\mathrm{so}}=2.8 \times 10^{-10}\right)>\mathrm{Br}^{-}$ $\left(\mathrm{K}_{\mathrm{so}}=5.2 \times 10^{-13}\right)>\mathrm{I}^{-}\left(\mathrm{K}_{\mathrm{so}}=8.5 \times 10^{-17}\right)$, in the reverse order of their occurrence in natural waters and in the order of increasing toxicity for their corresponding DBPs. Even in excess of chloride, which is typical for natural waters, bromide and iodide can be selectively removed from solution using silver ions. Silver may be immobilised in carbon aerogels[87,88], polymeric beads or on activated carbon surface (silver impregnated activated carbon)[90,91] or directly used as nanoparticles[92]. $\mathrm{AgCl}$ has also been tested to remove iodide by ion exchange[93]. This has not been implemented to full-scale treatment plant to date. More work is needed to confirm the impact of competing anions and to better understand the extent of silver leaching from these materials.

The different strategies for the removal of halides, including membrane filtration or ion exchange have been reviewed by Watson et al.[94]. Recently Br-selective anion exchange resins showed good performances for an efficient control of Br-DBPs, including in presence of competing anions and/or DOM[95].

\subsection{Mitigation of I-DBPs}

\subsubsection{The chlorine ammonia process}

During chloramination HOI is formed and is stable in solution inducing a high formation of I-DBPs. A process based on free chlorine followed by ammonia addition to form chloramine has been proposed in several studies[30,31,56,96]. This process intends, in a first step, to mitigate the formation of I-DBPs by converting most of iodide to iodate during pre-chlorination. In a second step, to quench the chlorine by addition of ammonia to form chloramine which is less reactive with DOM and control the formation of regulated chlorinated and brominated DBPs. The presence of bromide enhances the formation of iodate[30] and can reduce the pre-chlorination contact time but it may also increase the formation of 
more toxic Br-I-DBPs such as $\mathrm{CHBr}_{2} \mathrm{I}$ (compared to $\mathrm{CHCl}_{2} \mathrm{I}$ )[56]. For low bromide concentrations, a long contact time is needed to allow the full conversion of iodide to iodate and to mitigate the formation of I-DBPs. For high concentrations of bromide, a short chlorination contact time could be sufficient to limit the formation of I-DBPs. Furthermore, for highly reactive DOM, a pre-chlorination step is not beneficial compared to preformed monochloramine[56]. Overall, the process efficiency is highly depended on the DOM concentration and reactivity, the bromide concentration and the pre-chlorination contact time.

\subsubsection{Selective oxidation of iodide to iodate by ozone for I-DBP mitigation}

Ozone readily reacts with iodide and $\mathrm{HOI}$ to form iodate and is an attractive option to mitigate the formation of I-DBPs. However, the downside of using ozone is the formation of bromate since in most natural waters containing iodide, bromide is present at significant concentration. It was shown that it is possible to fully oxidised iodide to iodate while keeping the bromate concentration below the guideline value by using ozone[97]. This is based on the difference between the kinetic of bromide/bromine and iodide/iodine reactivity with ozone. Table 1 and 2 shows that iodide will be fully oxidised to iodate in less than $1 \mathrm{~ms}$ (at pH 7 and $1 \mathrm{mg} \mathrm{L}^{-1}$ Ozone) while the formation of bromate will take several minutes. Therefore, it is possible by applying an appropriate ozone dose to mitigate the formation of I-DBPs while controlling the bromate formation. In addition, the oxidation of the different hypohalous acids and hypohalite ions by ozone are dramatically different (Table 2 ). $\mathrm{HOI}$ and $\mathrm{IO}^{-}$are both rapidly oxidised $\left(\mathrm{k}=3.6 \times 10^{4}\right.$ and $1.6 \times 10^{6} \mathrm{M}^{-1} \mathrm{~s}^{-1}$ respectively) while only $\mathrm{BrO}^{-}$is reacting with ozone $\left(\mathrm{k}=110 \mathrm{M}^{-1} \mathrm{~s}^{-}\right.$ ${ }^{1}$ ). Therefore, lowering the $\mathrm{pH}$ to below 8.3 (pKa of $\mathrm{HOBr} / \mathrm{BrO}^{-}[23]$ ) to shift the equilibrium of the reactive bromine to $\mathrm{HOBr}$ further decreased the formation of bromate while the iodate formation is not significantly affected. Allard et al.[97] demonstrated that it was possible to fully oxidised iodide to iodate while keeping the bromate concentration below $10 \mu \mathrm{g} \mathrm{L}^{-1}$ for a wide range of bromide concentrations up to $940 \mu \mathrm{g} \mathrm{L} \mathrm{L}^{-1}$. 


\subsection{Strategies to mitigate the formation of bromate during ozonation}

While $\mathrm{HOBr}$ is formed during ozonation, the formation of organic Br-DBPs is usually low [28]. The main halogenated by-product of concern during ozonation is bromate due to its potential human carcinogen classification. Therefore, different mitigation strategies to control the bromate concentration below the drinking water quality standard $\left(10 \mu \mathrm{g} \mathrm{L}^{-1}\right)$ have been proposed. Among the mitigation processes, $\mathrm{pH}$ depression and ammonia addition are the most suitable at industrial scale[28].

As previously mentioned, lowering the $\mathrm{pH}$ favours the presence of $\mathrm{HOBr}$ which is less reactive towards ozone compared to $\mathrm{BrO}^{-}$and mitigates the formation of bromate (Table 2). In addition, a lower $\mathrm{pH}$ increases the ozone stability which in turn reduces the formation of $\mathrm{OH}$ radicals that are a main contributor to the formation of bromate[98].

In order to quench $\mathrm{HOBr}$, a key intermediate in the formation of bromate, ammonia may be added to the water. Bromamines are then formed and hinder the formation of bromate[98]. This mitigation strategy quench $\mathrm{HOBr}$, but does not limit the radical pathway and is limited by the amount of ammonia addition inducing a reduction of the bromate formation[98].

Similar to the mitigation of iodide, the chlorine ammonia process may be used prior to ozonation[99]. In this process, chlorine will oxidise bromide to $\mathrm{HOBr}$. $\mathrm{HOBr}$ is then quenched with ammonia to form bromamines and the formation of bromate mitigated. Buffle et al.[99] reduced the bromate formation by a factor of 4 using this process. The addition of hydrogen peroxide has also been proposed to reduce the formation of bromate. An optimal dosage of $\mathrm{H}_{2} \mathrm{O}_{2}$ is needed because an increasing concentration of peroxide may induce an increase in bromate formation. However, this AOP may induce a decrease of the disinfection efficiency by favouring the radical pathway and is then unsuitable for industrial processes. 


\subsection{Pre-oxidation for Br-DBPs mitigation}

Oxidants such as $\mathrm{HOCl}, \mathrm{O}_{3}, \mathrm{KMnO}_{4}, \mathrm{ClO}_{2}$ and $\mathrm{Fe}(\mathrm{VI})$ (the latter only in research) have been widely used as pre-treatment options. These oxidants have been applied successfully to reduce the formation of regulated DBPs during post-chlorination by reducing the reactivity of the DOM. However, in some cases, an increase or a similar formation of Br-DBPs has been observed[60,100,101]. Applying $\mathrm{O}_{3}$, $\mathrm{KMnO}_{4}, \mathrm{ClO}_{2}$ or $\mathrm{Fe}(\mathrm{VI})$ as a pre-treatment oxidizes reactive moieties in the DOM, which renders them typically less reactive towards chlorine or bromine in post-disinfection, thereby affecting the subsequent formation of Br-DBPs. The reactivity of the above oxidants toward DOM varies significantly[102] in the order $\mathrm{O}_{3}>>\mathrm{ClO}_{2}, \mathrm{Fe}(\mathrm{VI})>\mathrm{MnO}_{4}{ }^{-}$. Since the bromide oxidation by ozone is a relatively slow process, a selective oxidation of fast reacting DOM-moieties is possible, with negligible formation of $\mathrm{HOBr} / \mathrm{Br}-\mathrm{DBPs}$ or bromate. A good correlation was observed between the abatement of DOM reactivity characterized by the UV absorbance at $254 \mathrm{~nm}\left(\mathrm{UV}_{254}\right)$ and the electron donating capacity (EDC) and the total halogenated organic compounds formation[103]. However, in many cases the concentration of Br-DBPs increased after pre-oxidation. The pre-oxidant dose should be optimized to decrease the reactivity of the matrix while controlling the toxicity induced by the formation of brominated DBPs, notably brominated HANs[60].

\subsection{Removal of preformed DBPs by activated carbon adsorption}

Activated carbon may be used to remove halogenated disinfection by-products after a pre-chlorination step to some extents. According to the Freundlich adsorption constants, the adsorption of regulated THMs increased with increasing bromine content[104]. This is in agreement with results obtained from a full scale drinking water treatment plant where the removal efficiency of Cl-Br-THM by Granular Activated Carbon (GAC) ranged from 15 to $58 \%$ with $15 \%$ for $\mathrm{CHCl}_{3}, 18 \%$ for $\mathrm{CHBrCl}_{2}, 43 \%$ for $\mathrm{CHBr}_{2} \mathrm{Cl}$ and $58 \%$ for $\mathrm{CHBr}_{3}[59]$. A similar trend has been observed for I-THMs, with much higher removal rates: $77 \%$ for $\mathrm{CHCl}_{2} \mathrm{I}, 88 \%$ for $\mathrm{CHBrClI}, 94 \%$ for $\mathrm{CHBr}_{2} \mathrm{I}$ and $96 \%$ for $\mathrm{CHClI}_{2}$, increasing with the molecular weight and hydrophobicity[59]. No clear trend could be obtained for HAAs, rising 
questions around the mechanisms of HAAs removal and the partition between adsorption and biodegradation[59,105,106].

Recently several studies showed the benefit to perform a pre- or intermediate chlorination followed by GAC adsorption to lower the DBPs and total organic halogens formed during final disinfection[59,107110]. While a concomitant reduction of toxicity has been suggested[108,109], the reduction of calculated cytotoxicity could be rather low due to the formation of brominated and nitrogenous compounds (e.g. tribromonitromethane)[109]. Erdem et al.[111] showed that the adsorption of halogenated DBPs precursors mainly occurs in the mesoporous areas of the GAC and suggested that basic GAC would be more favourable as the oxidant residual increases the surface acidity, which impairs the adsorption of halogenated precursors.

\subsection{Air Stripping for removal of volatile DBPs}

Air stripping for DBPs mitigation has been implemented mainly in the US for the control of regulated THMs in small utilities. While efficient for chloroform, which exhibit the highest Henry's constant $\left(2.99 \times 10^{-3} \mathrm{~atm} \mathrm{~m}^{3} \mathrm{~mol}^{-1}\right)$, this process is less efficient for brominated THMs (e.g. Henry's constant for bromoform $\left.=5.35 \times 10^{-4} \mathrm{~atm} \mathrm{~m}^{3} \mathrm{~mol}^{-1}\right)[112]$ and not useful for non-volatile and more toxic DBPs like HAN or HAA for example.

\section{Conclusion}

Reactive bromine and iodine species may be formed during different oxidative processes. The propensity of disinfectants to form hypohalous acids and the lifespan of these species are key factors in the formation of halogenated DBPs. Chloramination has been shown to be at high risk for organic IDBP formation as chloramine rapidly forms HOI but cannot further oxidise it to the non-toxic iodate, in contrast to ozone and chlorine. High concentrations of bromide and iodide are usually associated with a higher formation of $\mathrm{Br}$ - and I-DBPs that are more toxic than their chlorinated analogues and consequently induced a higher toxicity risk. However, some beneficial effects of the presence of halides 
are found such as the enhancement of micropollutant and estrogenicity removal during oxidative treatment. Due to the high risk related to the $\mathrm{Br}$ - and I-DBPs, the removal of their precursors is an attractive option to limit their formation. So far, no industrial processes are available to specifically remove iodide and bromide, however the new designed $\mathrm{Br}$-specific-ion exchange resins look promising. Enhanced DOM removal could therefore be beneficial, but very low DOC concentrations are necessary in order to minimise the formation of such DBPs. Therefore, sustainable processes are needed to treat halide-impacted waters, especially considering the recurring droughts and increasing water scarcity that many urban metropolises are experiencing. 


\section{References}

[1] S. W. Krasner, in Disinfection by-products and human health, IWA Publishing., 2012, pp. 5971.

[2] H. Dong, Z. Qiang and S. D. Richardson, Formation of Iodinated Disinfection Byproducts (IDBPs) in Drinking Water: Emerging Concerns and Current Issues, Acc. Chem. Res., 2019, 52, 896905.

[3] P. A. Neale, A. Antony, M. E. Bartkow, M. J. Farré, A. Heitz, I. Kristiana, J. Y. M. Tang and B. I. Escher, Bioanalytical assessment of the formation of disinfection byproducts in a drinking water treatment plant, Environ. Sci. Technol., 2012, 46, 10317-10325.

[4] E. D. Wagner and M. J. Plewa, CHO cell cytotoxicity and genotoxicity analyses of disinfection by-products: An updated review, Journal of Environmental Sciences, 2017, 58, 64-76.

[5] Y. Yang, Y. Komaki, S. Y. Kimura, H.-Y. Hu, E. D. Wagner, B. J. Mariñas and M. J. Plewa, Toxic impact of bromide and iodide on drinking water disinfected with chlorine or chloramines, Environ. Sci. Technol., 2014, 48, 12362-12369.

[6] R. C. Hansson, M. J. Henderson, P. Jack, and R. D. Taylor, Iodoform taste complaints in chloramination, Water Research 21 (10), 1987, 1265-1271.

[7] B. Cancho, C. Fabrellas, A. Diaz, F. Ventura and M. T. Galceran, Determination of the Odor Threshold Concentrations Of Iodinated Trihalomethanes in Drinking Water, Journal of Agricultural and Food Chemistry, 2001, 49, 1881-1884.

[8] R. S. Magazinovic, B. C. Nicholson, D. E. Mulcahy and D. E. Davey, Bromide levels in natural waters: its relationship to levels of both chloride and total dissolved solids and the implications for water treatment, Chemosphere, 2004, 57, 329-335.

[9] Y. Gruchlik, J. Tan, S. Allard, A. Heitz, M. Bowman, D. Halliwell, U. von Gunten, J. Criquet and C. A. Joll, . Water - Journal of the Australian water association, 2014, 38-43.

[10] R. Salminen, M. J. Batista, M. Bidovec, and T. Tarvainen, Geochemical Atlas of Europe. Part 1 - Background Information, Methodology and Maps, Geological Survey of Finland, Otamedia Oy, Espoo, 2005.

[11] R. Fuge, Iodine in waters: possible links with endemic goitre, Applied Geochemistry, 1989, 4, 203-208. 
[12] F. J. Millero, R. Feistel, D. G. Wright and T. J. McDougall, The composition of Standard Seawater and the definition of the Reference-Composition Salinity Scale, Deep Sea Research Part I: Oceanographic Research Papers, 2008, 55, 50-72.

[13] J. Risher, G. Diamond, S. G. Swarts, and R. Amata, Toxicological profile for iodine, Toxicological profile for iodine U.S. DEPARTMENT OF HEALTH AND HUMAN SERVICES Public Health Service Agency for Toxic Substances and Disease Registry, 2004.

[14] Q. Tang, Q. Xu, F. Zhang, Y. Huang, J. Liu, X. Wang, Y. Yang and X. Liu, Geochemistry of iodine-rich groundwater in the Taiyuan Basin of central Shanxi Province, North China, Journal of Geochemical Exploration, 2013, 135, 117-123.

[15] F. Soltermann, C. Abegglen, C. Götz and U. Von Gunten, Bromide Sources and Loads in Swiss Surface Waters and Their Relevance for Bromate Formation during Wastewater Ozonation, Environ. Sci. Technol., 2016, 50, 9825-9834.

[16] J. L. Kormos, M. Schulz and T. A. Ternes, Occurrence of Iodinated X-ray Contrast Media and Their Biotransformation Products in the Urban Water Cycle, Environ. Sci. Technol., 2011, 45, 87238732.

[17] J. S. Harkness, G. S. Dwyer, N. R. Warner, K. M. Parker, W. A. Mitch and A. Vengosh, Iodide, Bromide, and Ammonium in Hydraulic Fracturing and Oil and Gas Wastewaters: Environmental Implications, Environ. Sci. Technol., 2015, 49, 1955-1963.

[18] K. Kumar and D. W. Margerum, Kinetics and Mechanism of General-Acid-Assisted Oxidation of Bromide by Hypochlorite and Hypochlorous Acid, Inorganic Chemistry, 1987, 26, 2706-2711.

[19] I. Fábián and G. Gordon, The kinetics and mechanism of the chlorine dioxide- iodide ion reaction, Inorganic chemistry, 1997, 36, 2494-2497.

[20] J. C. Nagy, K. Kumar, and D. W. Margerum, Non-Metal Redox Kinetics: Oxidation of Iodide by Hypochlorous Acid and by Nitrogen Trichloride Measured by the Pulsed-Accelerated-Flow Method Inorganic Chemistry, Vol. 27, No. 16, 1988, 2773-2780.

[21] C. M. Gerritsen and D. W. Margerum, Non-metal redox kinetics: hypochlorite and hypochlorous acid reactions with cyanide, Inorganic Chemistry, 1990, 29, 2757-2762.

[22] R. C. Troy and D. W. Margerum, Non-metal redox kinetics: Hypobromite and hypobromous acid reactions with iodide and with sulfite and the hydrolysis of bromosulfate, Inorganic Chemistry, 1991, 30, 3538-3543. 
[23] W. R. Haag and Juerg. Hoigne, Ozonation of bromide-containing waters: kinetics of formation of hypobromous acid and bromate, Environ. Sci. Technol., 1983, 17, 261-267.

[24] Q. Liu, L. M. Schurter, C. E. Muller, S. Aloisio, J. S. Francisco and D. W. Margerum, Kinetics and Mechanisms of Aqueous Ozone Reactions with Bromide, Sulfite, Hydrogen Sulfite, Iodide, and Nitrite Ions, Inorganic Chemistry, 2001, 40, 4436-4442.

[25] K. Kumar, R. A. Day, and D. W. Margerum, Atom-Transfer Redox Kinetics: General-AcidAssisted Oxidation of Iodide by Chloramines and Hypochlorite, Inorganic Chemistry 25, 1986, 43444350.

[26] M. B. Heeb, J. Criquet, S. G. Zimmermann-Steffens and U. von Gunten, Oxidative treatment of bromide-containing waters: Formation of bromine and its reactions with inorganic and organic compounds - A critical review, Water Research, 2014, 48, 15-42.

[27] J. Hoigne and H. Bader, Kinetics of reactions of chlorine dioxide $(\mathrm{OClO})$ in water-I. Rate constants for inorganic and organic compounds, Wat. Res., 1994, 28, 45-55.

[28] U. von Gunten, Ozonation of drinking water: Part II. Disinfection and by-product formation in presence of bromide, iodide or chlorine, Water Research, 2003, 37, 1469-1487.

[29] H. Bürgi, Th. Schaffner and J. P. Seiler, The Toxicology of Iodate: A Review of the Literature, Thyroid, 2001, 11, 449-456.

[30] J. Criquet, S. Allard, E. Salhi, C. A. Joll, A. Heitz and U. von Gunten, Iodate and IodoTrihalomethane Formation during Chlorination of Iodide-Containing Waters: Role of Bromide, Environmental Science \& Technology, 2012, 46, 7350-7357.

[31] Y. Bichsel and U. von Gunten, Oxidation of Iodide and Hypoiodous Acid in the Disinfection of Natural Waters, Environmental Science \& Technology, 1999, 33, 4040-4045.

[32] R. C. Beckwith and D. W. Margerum, Kinetics of Hypobromous Acid Disproportionation, Inorganic Chemistry, 1997, 36, 3754-3760.

[33] M. Langsa, S. Allard, I. Kristiana, A. Heitz and C. A. Joll, Halogen-specific total organic halogen analysis: Assessment by recovery of total bromine, Journal of Environmental Sciences, 2017, $58,340-348$.

[34] Y. Bichsel and U. von Gunten, Formation of Iodo-Trihalomethanes during Disinfection and Oxidation of Iodide-Containing Waters, Environmental Science \& Technology, 2000, 34, 2784-2791. 
Reaction of bromine and chlorine with phenolic compounds and natural organic matter extracts Electrophilic aromatic substitution and oxidation, Water Research, 2015, 85, 476-486.

[36] G. Hua, D. A. Reckhow and J. Kim, Effect of Bromide and Iodide Ions on the Formation and Speciation of Disinfection Byproducts during Chlorination, Environmental Science \& Technology, 2006, 40, 3050-3056.

[37] G. L. Amy, P. A. Chadik, P. H. King and W. J. Cooper, Chlorine utilization during trihalomethane formation in the presence of ammonia and bromide, Environ. Sci. Technol., 1984, 18, 781-786.

[38] H. Gallard, F. Pellizzari, J. P. Croué and B. Legube, Rate constants of reactions of bromine with phenols in aqueous solution, Water Research, 2003, 37, 2883-2892.

[39] Y. Lee and U. von Gunten, Transformation of 17 $\alpha$-Ethinylestradiol during Water Chlorination: Effects of Bromide on Kinetics, Products, and Transformation Pathways, Environ. Sci. Technol., 2009, $43,480-487$.

[40] T. Bond, O. Henriet, E. H. Goslan, S. A. Parsons and B. Jefferson, Disinfection Byproduct Formation and Fractionation Behavior of Natural Organic Matter Surrogates, Environ. Sci. Technol., $2009,43,5982-5989$.

[41] Y. Lee, J. Yoon and U. von Gunten, Kinetics of the Oxidation of Phenols and Phenolic Endocrine Disruptors during Water Treatment with Ferrate (Fe(VI)), Environ. Sci. Technol., 2005, 39, 8978-8984.

[42] S. E. Duirk, B. Gombert, J.-P. Croué and R. L. Valentine, Modeling monochloramine loss in the presence of natural organic matter, Water Research, 2005, 39, 3418-3431.

[43] M. B. Heeb, I. Kristiana, D. Trogolo, J. S. Arey and U. von Gunten, Formation and reactivity of inorganic and organic chloramines and bromamines during oxidative water treatment, Water Research, 2017, 110, 91-101.

[44] P. J. Vikesland, K. Ozekin and R. L. Valentine, Monochloramine decay in model and distribution system waters, Water Research, 2001, 35, 1766-1776.

[45] M. Gazda and D. W. Margerum, Reactions of monochloramine with bromine, tribromide, hypobromous acid and hypobromite: formation of bromochloramines, Inorg. Chem., 1994, 33, 118123. 
[46] T. W. Trofe, G. W. Jr. Inman and J. D. Johnson, Kinetics of Monochloramine Decomposition in the Presence of Bromide, Environmental Science \& Technology, 1980, 14, 544-549.

[47] J. Edmund. Wajon and J. Carrell. Morris, Rates of formation of N-bromo amines in aqueous solution, Inorg. Chem., 1982, 21, 4258-4263.

[48] S. E. Duirk and R. L. Valentine, Bromide oxidation and formation of dihaloacetic acids in chloraminated water, Environmental Science and Technology, 2007, 41, 7047-7053.

[49] P. G. Pope and G. E. Speitel, in Disinfection By-Products in Drinking Water, American Chemical Society, 2008, vol. 995, pp. 182-197.

[50] R. L. Valentine, Bromochloramine oxidation of N,N-diethyl-p-phenylenediamine in the presence of monochloramine, Environ. Sci. Technol., 1986, 20, 166-170.

[51] S. Allard, K. Cadee, R. Tung and J.-P. Croué, Impact of brominated amines on monochloramine stability during in-line and pre-formed chloramination assessed by kinetic modelling, Science of the Total Environment, 2018, 618, 1431-1439.

[52] W. Lee and P. Westerhoff, Formation of organic chloramines during water disinfection chlorination versus chloramination, Water Research, 2009, 43, 2233-2239.

[53] S. D. Richardson, F. Fasano, J. J. Ellington, F. G. Crumley, K. M. Buettner, J. J. Evans, B. C. Blount, L. K. Silva, T. J. Waite, G. W. Luther, and others, Occurrence and mammalian cell toxicity of iodinated disinfection byproducts in drinking water, Environmental science \& technology, 2008, 42, 8330-8338.

[54] M. J. Plewa, M. G. Muellner, S. D. Richardson, F. Fasano, K. M. Buettner, Y.-T. Woo, A. B. Mckague and E. D. Wagner, Occurrence, synthesis, and mammalian cell cytotoxicity and genotoxicity of haloacetamides: An emerging class of nitrogenous drinking water disinfection byproducts, Environmental Science and Technology, 2008, 42, 955-961.

[55] S. S. Lau, X. Wei, K. Bokenkamp, E. D. Wagner, M. J. Plewa and W. A. Mitch, Assessing Additivity of Cytotoxicity Associated with Disinfection Byproducts in Potable Reuse and Conventional Drinking Waters, Environmental Science and Technology, 2020, 54, 5729-5736.

[56] S. Allard, J. Tan, C. A. Joll and U. von Gunten, Mechanistic Study on the Formation of Cl-/Br/I-Trihalomethanes during Chlorination/Chloramination Combined with a Theoretical Cytotoxicity Evaluation, Environmental Science \& Technology, 2015, 49, 11105-11114. 

Byproduct Formation in Waters Treated with Chlorine and Iodine: Relevance to Point-of-Use Treatment, Environmental Science \& Technology, 2010, 44, 8446-8452.

[58] M. S. Ersan, C. Liu, G. Amy and T. Karanfil, The interplay between natural organic matter and bromide on bromine substitution, Science of the Total Environment, 2019, 646, 1172-1181.

[59] H. MacKeown, J. Adusei Gyamfi, K. V. K. M. Schoutteten, D. Dumoulin, L. Verdickt, B. Ouddane and J. Criquet, Formation and removal of disinfection by-products in a full scale drinking water treatment plant, Science of the Total Environment, 2020, 704, 135280.

[60] V. Rougé, U. Von Gunten, M. Lafont De Sentenac, M. Massi, P. J. Wright, J.-P. Croué and S. Allard, Comparison of the impact of ozone, chlorine dioxide, ferrate and permanganate pre-oxidation on organic disinfection byproduct formation during post-chlorination, Environmental Science: Water Research and Technology, 2020, 6, 2382-2395.

[61] M. J. Plewa, E. D. Wagner and S. D. Richardson, TIC-Tox: A preliminary discussion on identifying the forcing agents of DBP-mediated toxicity of disinfected water, Journal of Environmental Sciences, 2017, 58, 208-216.

[62] Z. Pan, Y. Zhu, M. Wei, Y. Zhang and K. Yu, Interactions of fluoroquinolone antibiotics with sodium hypochlorite in bromide-containing synthetic water: Reaction kinetics and transformation pathways, Journal of Environmental Sciences (China), 2021, 102, 170-184.

[63] J. Choi, S. E. Duirk and R. L. Valentine, Mechanistic studies of N-nitrosodimethylamine (NDMA) formation in chlorinated drinking water, J. Environ. Monit., 2002, 4, 249-252.

[64] J. Choi and R. L. Valentine, Formation of N-nitrosodimethylamine (NDMA) from reaction of monochloramine: A new disinfection by-product, Water Research, 2002, 36, 817-824.

[65] W. A. Mitch and D. L. Sedlak, Formation of N-Nitrosodimethylamine (NDMA) from Dimethylamine during Chlorination, Environ. Sci. Technol., 2002, 36, 588-595.

[66] J. Luh and B. J. Mariñas, Bromide ion effect on $\mathrm{N}$-nitrosodimethylamine formation by monochloramine, Environmental Science and Technology, 2012, 46, 5085-5092.

[67] W. Beita-Sandí, C. U. Erdem and T. Karanfil, Effect of bromide on NDMA formation during chloramination of model precursor compounds and natural waters, Water Research, 2020, 186, 115323.

[68] T. Jasemizad, L. Bromberg, T. A. Hatton and L. P. Padhye, Oxidation of betrixaban to yield Nnitrosodimethylamine by water disinfectants, Water Research, , DOI:10.1016/j.watres.2020.116309. 

chloramination of tertiary amines: The influence of bromide ion, Environmental Science and Technology, 2012, 46, 1581-1589.

[70] U. von Gunten, E. Salhi, C. K. Schmidt and W. A. Arnold, Kinetics and Mechanisms of NNitrosodimethylamine Formation upon Ozonation of N,N-Dimethylsulfamide-Containing Waters: Bromide Catalysis, Environ. Sci. Technol., 2010, 44, 5762-5768.

[71] Y. Lee, B. I. Escher and U. Von Gunten, Efficient removal of estrogenic activity during oxidative treatment of waters containing steroid estrogens, Environmental Science and Technology, 2008, 42, 6333-6339.

[72] P. Abdallah, M. Deborde, F. Dossier Berne and N. Karpel Vel Leitner, Kinetics of Chlorination of Benzophenone-3 in the Presence of Bromide and Ammonia, Environmental Science and Technology, $2015,49,14359-14367$.

[73] C.-Y. Hu, Y.-G. Deng, Y.-L. Lin and Y.-Z. Hou, Chlorination of bromacil: Kinetics and disinfection by-products, Separation and Purification Technology, 2019, 212, 913-919.

[74] H. Zhang, C. Guo, J. Lv, S. Hou, Y. Zhang, J. Gao and J. Xu, Aqueous chlorination of ephedrine: Kinetic, reaction mechanism and toxicity assessment, Science of the Total Environment, $2020,740,140146$.

[75] H. Yoom, J. Shin, J. Ra, H. Son, D. Ryu, C. Kim and Y. Lee, Transformation of methylparaben during water chlorination: Effects of bromide and dissolved organic matter on reaction kinetics and transformation pathways, Science of the Total Environment, 2018, 634, 677-686.

[76] Q. Liu, X. Xu, L. Wang and D. Wang, Transformation reactivity of parent polycyclic aromatic hydrocarbons and the formation trend of halogenated polycyclic aromatic hydrocarbons in the presence of bromide ion during chlorination, Chemical Engineering Journal, 2020, 400, 125901.

[77] C.-Y. Hu, Y.-L. Lin, A.-P. Li and B. Xu, Degradation kinetics and disinfection by-product formation of chlorimuron-ethyl during aqueous chlorination, Separation and Purification Technology, 2018, 204, 49-55.

[78] X. Kong, L. Wang, Z. Wu, F. Zeng, H. Sun, K. Guo, Z. Hua and J. Fang, Solar irradiation combined with chlorine can detoxify herbicides, Water Research, 2020, 177, 115784.

[79] L. Wang, D. Kong, Y. Ji, J. Lu, X. Yin and Q. Zhou, Formation of halogenated disinfection byproducts during the degradation of chlorophenols by peroxymonosulfate oxidation in the presence of bromide, Chemical Engineering Journal, 2018, 343, 235-243. 
[80] F. Yang, B. Sheng, Z. Wang, R. Yuan, Y. Xue, X. Wang, Q. Liu and J. Liu, An oftenoverestimated adverse effect of halides in heat/persulfate-based degradation of wastewater contaminants, Environment International, 2019, 130, 104918.

[81] Z. Hua, D. Li, Z. Wu, D. Wang, Y. Cui, X. Huang, J. Fang and T. An, DBP formation and toxicity alteration during $\mathrm{UV} /$ chlorine treatment of wastewater and the effects of ammonia and bromide, Water Research, 2021, 188, 116549.

[82] S. Chellam and S. W. Krasner, Disinfection byproduct relationships and speciation in chlorinated nanofiltered waters, Environmental Science and Technology, 2001, 35, 3988-3999.

[83] J. M. Kemper, P. Westerhoff, A. Dotson and W. A. Mitch, Nitrosamine, Dimethylnitramine, and Chloropicrin Formation during Strong Base Anion-Exchange Treatment, Environ. Sci. Technol., 2009, 43, 466-472.

[84] S. W. Krasner, T. C. F. Lee, P. Westerhoff, N. Fischer, D. Hanigan, T. Karanfil, W. BeitaSandí, L. Taylor-Edmonds and R. C. Andrews, Granular Activated Carbon Treatment May Result in Higher Predicted Genotoxicity in the Presence of Bromide, Environ. Sci. Technol., 2016, 50, 95839591.

[85] Y. Zhang, W. Chu, D. Yao and D. Yin, Control of aliphatic halogenated DBP precursors with multiple drinking water treatment processes: Formation potential and integrated toxicity, Journal of Environmental Sciences, 2017, 58, 322-330.

[86] S. Ding, Y. Deng, T. Bond, C. Fang, Z. Cao and W. Chu, Disinfection byproduct formation during drinking water treatment and distribution: A review of unintended effects of engineering agents and materials, Water Research, 2019, 160, 313-329.

[87] M. Sánchez-Polo, J. Rivera-Utrilla, E. Salhi and U. von Gunten, Removal of bromide and iodide anions from drinking water by silver-activated carbon aerogels, Journal of Colloid and Interface Science, 2006, 300, 437-441.

[88] M. Sánchez-Polo, J. Rivera-Utrilla, E. Salhi and U. von Gunten, Ag-doped carbon aerogels for removing halide ions in water treatment, Water Research, 2007, 41, 1031-1037.

[89] M. Sánchez-Polo, J. Rivera-Utrilla and U. von Gunten, Bromide and iodide removal from waters under dynamic conditions by Ag-doped aerogels, Journal of Colloid and Interface Science, 2007, 306, 183-186.

[90] J. S. Hoskins, T. Karanfil and S. M. Serkiz, Removal and Sequestration of Iodide Using SilverImpregnated Activated Carbon, Environ. Sci. Technol., 2002, 36, 784-789. 

and iodide from natural waters using a novel $\mathrm{AgCl}$-SPAC composite at environmentally relevant conditions, Water Research, 2019, 156, 168-178.

[92] A. M. S. Polo, J. J. Lopez-Peñalver, J. Rivera-Utrilla, U. Von Gunten and M. Sánchez-Polo, Halide removal from waters by silver nanoparticles and hydrogen peroxide, Science of the Total Environment, 2017, 607-608, 649-657.

[93] T. Karanfil, E. C. Moro and S. M. Serkiz, Development and testing of a silver chlorideimpregnated activated carbon for aqueous removal and sequestration of iodide, Environmental Technology, 2005, 26, 1255-1262.

[94] K. Watson, M. J. Farré and N. Knight, Strategies for the removal of halides from drinking water sources, and their applicability in disinfection by-product minimisation: A critical review, Journal of Environmental Management, 2012, 110, 276-298.

[95] M. Soyluoglu, M. S. Ersan, M. Ateia and T. Karanfil, Removal of bromide from natural waters: Bromide-selective vs. conventional ion exchange resins, Chemosphere, 2020, 238, 124583

[96] D. B. Jones, A. Saglam, A. Triger, H. Song and T. Karanfil, I-THM Formation and Speciation: Preformed Monochloramine versus Prechlorination Followed by Ammonia Addition, Environmental Science \& Technology, 2011, 45, 10429-10437.

[97] S. Allard, C. E. Nottle, A. Chan, C. Joll and U. von Gunten, Ozonation of iodide-containing waters: Selective oxidation of iodide to iodate with simultaneous minimization of bromate and I-THMs, Water Research, 2013, 47, 1953-1960.

[98] U. von Gunten, Ozonation of drinking water: Part I. Oxidation kinetics and product formation, Water Research, 2003, 37, 1443-1467.

[99] M.-O. Buffle, S. Galli and U. Von Gunten, Enhanced bromate control during ozonation: The chlorine-ammonia process, Environmental Science and Technology, 2004, 38, 5187-5195.

[100] G. Hua and D. A. Reckhow, Effect of pre-ozonation on the formation and speciation of DBPs, Water Research, 2013, 47, 4322-4330.

[101] X. Yang, W. Guo and W. Lee, Formation of disinfection byproducts upon chlorine dioxide preoxidation followed by chlorination or chloramination of natural organic matter, Chemosphere, 2013, 91, 1477-1485.

[102] M. K. Ramseier, U. von Gunten, P. Freihofer and F. Hammes, Kinetics of membrane damage to high (HNA) and low (LNA) nucleic acid bacterial clusters in drinking water by ozone, chlorine, 
chlorine dioxide, monochloramine, ferrate(VI), and permanganate, Water Research, 2011, 45, 14901500 .

[103] V. Rougé, U. von Gunten and S. Allard, Efficiency of pre-oxidation of natural organic matter for the mitigation of disinfection byproducts: Electron donating capacity and UV absorbance as surrogate parameters, Water Research, 2020,187, 116418.

[104] T. F. Speth and R. J. Miltner, Technical note. Adsorption capacity of GAC for synthetic organics, Journal / American Water Works Association, 1990, 82, 72-75.

[105] H.-H. Tung, R. F. Unz and Y. F. Xie, HAA removal by GAC adsorption, Journal - American Water Works Association, 2006, 98, 107-112.

[106] J. Kim and B. Kang, DBPs removal in GAC filter-adsorber, Water Research, 2008, 42, 145152.

[107] J. Jiang, X. Zhang, X. Zhu and Y. Li, Removal of Intermediate Aromatic Halogenated DBPs by Activated Carbon Adsorption: A New Approach to Controlling Halogenated DBPs in Chlorinated Drinking Water, Environmental Science and Technology, 2017, 51, 3435-3444.

[108] J. Jiang, W. Li, X. Zhang, J. Liu and X. Zhu, A new approach to controlling halogenated DBPs by GAC adsorption of aromatic intermediates from chlorine disinfection: Effects of bromide and contact time, Separation and Purification Technology, 2018, 203, 260-267.

[109] A. Cuthbertson, S. Kimura, H. Liberatore, R. Scott Summers, D. Knappe, B. D. Stanford, J. Clark Maness, R. Mulhern, M. Selbes and S. Richardson, Does GAC with Chlorination Produce Safer Drinking Water? From DBPs and TOX to Calculated Toxicity, Environmental Science \& Technology, 2019, 53, 5987-5999.

[110] A. A. Cuthbertson, S. Y. Kimura, H. K. Liberatore, D. R. U. Knappe, B. Stanford, R. S. Summers, E. R. Dickenson, J. C. Maness, C. Glover, M. Selbes and S. D. Richardson, GAC to BAC: Does it make chloraminated drinking water safer?, Water Research, 2020,172, 115432

[111] C. U. Erdem, M. Ateia, C. Liu and T. Karanfil, Activated carbon and organic matter characteristics impact the adsorption of DBP precursors when chlorine is added prior to GAC contactors, Water Research, 2020, 184, 116146.

[112] E. C. Inniss, S. R. Poleneni, C. M. Roberts, R. E. Reed and T. E. Clevenger, Approaches to optimizing DBP compliance in small water utilities Water Quality Technology Conference and Exposition 2012. 
[113] J. Pals, J. Ang, E. D. Wagner, M. J. Plewa, Biological mechanism for the toxicity of haloacetic acid drinking water disinfection byproducts. Environ. Sci. Technol., 2011, 45, 5791-5797.

\section{Tables}

Table 1. Second order rate constants of bromide and iodide oxidation by principal oxidants used in drinking water treatment and half - life $\left(\mathrm{t}_{1 / 2}\right)$ of halides for $1 \mathrm{mg} / \mathrm{L}$ of oxidant at $\mathrm{pH} 7$.

\begin{tabular}{|c|c|c|c|c|c|c|}
\hline Oxidant & $\begin{array}{c}\text { Second } \\
\text { order rate } \\
\text { constant k } \\
\left(\mathrm{M}^{-1} \mathrm{~s}^{-1}\right) \\
\end{array}$ & $\begin{array}{c}\mathbf{B r}^{-} \\
\mathrm{t}_{1 / 2} \text { at } \mathrm{pH} 7 \\
\text { (s) }\end{array}$ & References & $\begin{array}{c}\text { Second } \\
\text { order rate } \\
\text { constant } \mathrm{k} \\
\left(\mathrm{M}^{-1} \mathrm{~s}^{-1}\right) \\
\end{array}$ & $\begin{array}{c}\mathbf{I}^{-} \\
\mathrm{t}_{1 / 2} \text { at } \mathrm{pH} 7 \\
\text { (s) }\end{array}$ & References \\
\hline \multicolumn{7}{|c|}{ HOX producing processes } \\
\hline $\begin{array}{l}\mathrm{HOCl} \\
\mathrm{ClO}^{-}\end{array}$ & $\begin{array}{c}1550 \\
9 \times 10^{-4}\end{array}$ & 33 & [18] & $\begin{array}{c}4.3 \times 10^{8} \\
<30\end{array}$ & $10^{-4}$ & {$[20,21]$} \\
\hline $\begin{array}{l}\text { HOBr } \\
\text { BrO- }^{-}\end{array}$ & & & & $\begin{array}{c}5 \times 10^{9} \\
6.8 \times 10^{5}\end{array}$ & $10^{-5}$ & {$[22]$} \\
\hline $\mathbf{O}_{3}$ & 160 & 208 & [23] & $2 \times 10^{9}$ & $10^{-5}$ & [24] \\
\hline $\mathrm{NH}_{2} \mathrm{Cl}$ & & & & $\begin{array}{c}2.4 \times 10^{3} \text { at } \\
\mathrm{pH} 7\end{array}$ & 15 & {$[25]$} \\
\hline \multicolumn{7}{|c|}{ Non-HOX producing processes } \\
\hline $\mathrm{NH}_{2} \mathrm{Cl}$ & 0.14 at $\mathrm{pH} 7$ & $2.6 \times 10^{5}$ & [26] & & & \\
\hline $\mathrm{ClO}_{2}$ & $<10^{-4}$ & high & {$[27]$} & 1870 & 25 & [19] \\
\hline
\end{tabular}

ND: not determined 
Table 2. Second order rate constants of hypohalous and hypohalite oxidation by principal oxidants used in drinking water treatment and half time life $\left(\mathrm{t}_{1 / 2}\right)$ of these species for $1 \mathrm{mg} / \mathrm{L}$ of oxidant at $\mathrm{pH} 7$.

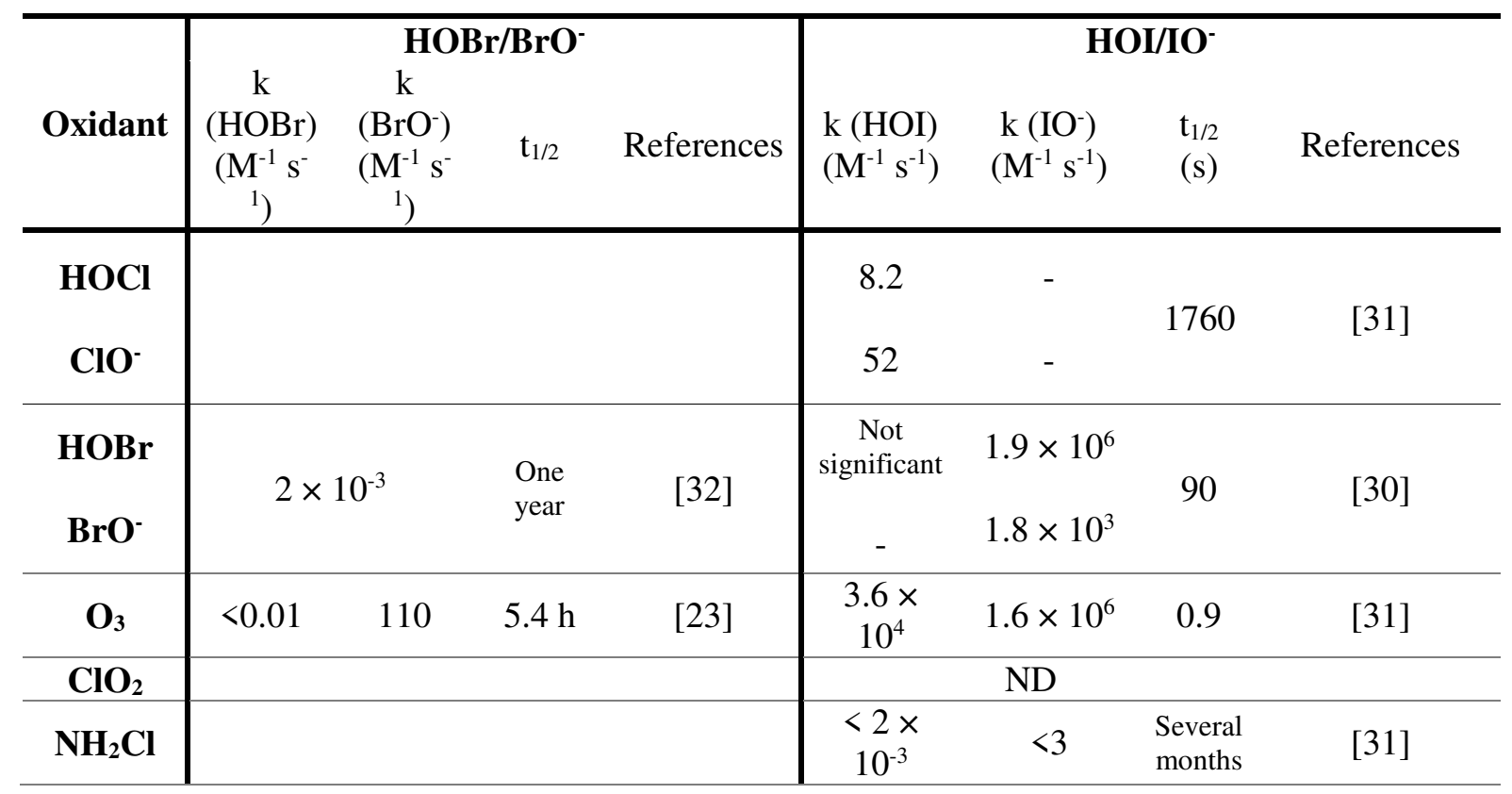

\section{Figure Captions}

Figure 1: General scheme of disinfection by-product formation in presence of bromide and iodide and relation to increasing toxicity of halogenated analogues in order $\mathrm{Cl}-<\mathrm{Br}-<\mathrm{I}-\mathrm{DBPs}$. Inset figure: Toxicity expressed as inhibition of GAPDH (glyceraldehyde-3-phosphate dehydrogenase) in CHO cells (Chinese Ovary Cells) treated with iodo-, bromo and chloro-acetic acids; reprinted with permission from [113]. Copyright (2011) American Chemical Society.

Figure 2: Formation pathway of halogenated DBPs during chlorination. The direct oxidation of DOM leads to the recycling of halides. 